\title{
Adult task-based and communicative L2 teaching and L2 teachers' search for complicity: $R$, a case study
}

\author{
José Ignacio Aguilar Río \\ Département Français Langue Étrangère \\ Université de Paris 3 Sorbonne Nouvelle
}

Received: 20 April 2008 / Accepted: 22 October 2008

ISSN: $1697-7467$

\begin{abstract}
Communicative and task-based foreign language (L2) teaching allow the use of participants' personal attitudes and circumstances in order to introduce linguistic and communicative elements in contexts accounting for conversational routines similar to those of the L2 community. Engaged in interactions resulting from such routines, teacher $R$ shifted at times from his L2 expert role to that of interaction participant, characterised by a feature described as search for complicity towards learners. By examining $R$ 's qualitative corpus of English classes, completed by interviews with $R$ and with learners, we point out some possible didactic implications from this search for complicity feature. Key words: L2 teaching/learning, L2 teacher, L2 learner, interaction, self-presentation.
\end{abstract}

Enseñanza comunicatica y enfocada por tareas de una L2 a adultos y búsqueda de la complicidad por parte del profesor: $R$, un estudio de casos

RESUMEN: El enfoque comunicativo y por tareas en enseñanza de lenguas extranjeras (L2) permite el empleo de informaciones personales para presentar elementos de la L2 en contextos que reproducen los de la comunidad meta. Durante las interacciones con los aprendices, el profesor $R$ alterna en ocasiones su papel de experto en la L2 con el de participante en la comunicación, caracterizado por una búsqueda de complicidad con los aprendices. A partir de extractos de sus clases de inglés y de entrevistas con $R$ y con los aprendices, nos interesamos por los posibles efectos didácticos de esta búsqueda de complicidad.

Palabras clave: enseñanza/aprendizaje de una L2, profesor de L2, aprendiz de L2 interacción, presentación de la persona.

\section{Communicative l2 teacher's Profile: to be at learners' SERVice}

According to the rationale of the so called $\operatorname{class}^{1}$, learning a foreign language (L2) requires for participants to acknowledge and embrace a series of interactional protocols and

1. The present paper will be considering L2 learning that implies the encounter between a teacher and a group of learners, whose motivations may be as varied as they are unknown to the observer; these encounters 
roles (Cicurel, 2002), in order for the limited exposure to the L2 to yield a maximum of learning-related benefit. Referred to by certain scholars as the contrat didactique (Cicurel, 2005: 3; Dausendshön-Gay \& Krafft, 1991: 47), an implicit agreement is thus passed among teacher and learners, stating that the improvement of L2 competences is the reason why participants meet on a regular basis, for a specific amount of time, and according to certain conditions established beforehand. This contrat didactique determines the roles and responsibilities proper to each of participants: in a few words, it is up to learners to learn the L2, whereas it is the teacher's duty to make sure that certain conditions be met in order for this learning to be possible ( $c f$. Berard, 1991: 58-59).

These necessary conditions may be of a material nature, in which case the aspects being considered would refer to making sure that the pedagogical resources needed for the encounter be ready (Berard, op. cit.: 58). Other conditions may refer to human-personal-social dimensions, according to which certain listening, managing, and relational skills will be expected from the teacher (Berard, op. cit: 102; Bogaards, 1988: 124; Noels 2001: 136; Nonnon 2004: 7779).

In order for learning processes to be significant for participants, communicative and task-based approaches to L2 learning ${ }^{2}$ often appeal to participants' personal involvement (Cicurel, 1998: 4; 2002: 148-149), as a means to have learners produce in the L2 (Berard, op. cit.: 56-57; Cicurel, 1988: 23). Learners' productions may activate teacher's attention a) by virtue of the information transmitted - teacher as a participant who may become interested by specific facts - or b) in relation to the structure learners' productions present - teacher as a L2 expert who decides about the propriety of learners' productions. Accordingly, the teacher may look at learners a) as individuals trying to accomplish a social identity within the context of the class (Mondada \& Pekarek, 2004: 504), or b) as L2 users whose mastery of the L2 shows that certain aspects leave room for improvement. In either case, and given the fact that the learners' new learning is the chief objective of the whole teaching/learning process, teacher is often considered as the least important participant (Bogaards, op. cit.: 100).

Consequently, it would seem convenient for L2 teachers to leave their own personal motivations aside while interacting with learners: this may guarantee that teachers adapt to learners' specific needs. However, we would like to argue that teaching approaches that lean substantially on the personal experiences and criterion of participants, such as communicative and task-based teaching ( $c f$. Berard, op. cit.: 56; Nunan, op. cit.: 94), may make it difficult for L2 teachers to keep the balance between their roles as L2 experts and communication participants (Berard, op. cit.: 102). Looking in detail to some excerpts from English as a foreign language (EFL) teacher $R$ 's classes, we aim to illustrate the alternation of these two roles, as well as its possible didactic implications.

\footnotetext{
suppose the physical presence of all participants, according to a schedule decided in advance by the institution (number of hours per week and per day, number of teachers working with one group, L2 contents and aspects covered, etc.). Hence, we will not be considering L2 learning that employs information and communication technologies, nor any other distant/self-learning scenarios ( $c f$. Narcy-Combes, 2005).

2. Conceived as the orderly and gradual presentation to learners of L2 contents, in order for them to manipulate these and hence be able to improve their L2 competences (Berard, op. cit.: 49).
} 


\section{Teacher R: PRESENTATION OF CORPUS}

The excerpts that will be presented in this paper have all been selected from an EFL corpus constituted as part of a classroom observation fieldwork carried out at the Language Centre Department of Glasgow University during the second half of April, 2007.

Teacher $R$ was observed twice - April 13 and 19, 2007 - while teaching an IELTS 4 preentry class ${ }^{3}$. The group observed consisted of thirteen male and female international learners from Asia and Middle-East, all of them young adults. Once the observations were completed, $R$ was interviewed: $R$ is a young (early 40s) experienced (some 16 years) EFL teacher who has worked in Asia and in Europe, and who has now been teaching in Britain for about ten years. At the University of Glasgow, $R$ teaches English for Academic Purposes (EAP) classes, trains trainee EFL/TESOL ${ }^{4}$ teachers in CELTA $^{5}$ courses organised at Glasgow University, and is also in charge of the supervision of MA and $\mathrm{PhD}$ students in the field of applied linguistics. $R$ also does research in sociolinguistics.

\section{Methodology}

$R$ 's classes were tape-recorded by the observer. The total time of recorded material for $R$ 's classes amounts to two hours and thirty-four minutes, whereas $R$ 's interview amounts to forty minutes. At the beginning of the first observation (13 of April), $R$ introduced the observer to learners, who was presented as a $\mathrm{PhD}$ student doing classroom research. As agreed beforehand with $R$, the observer addressed learners at the end of this first observation in order to give to them details about the current research and also to answer any questions they may have. Other than this intervention, the observer always remained a non participant, unless addressed to by $R$ - this happened only once or twice during the two observations and always for specific reasons (to open the window, to change places with a learner).

Recordings were transcribed following an amalgamation of DILTEC ${ }^{6}$ and ICAR $^{7}$ transcribing conventions. Our focus was directed to interactive sequences were $R$ 's conversational actions could be related to $R$ 's role as L2 expert, but also to sequences where $R$ 's actions would seem to correspond to those of a mere participant. Once any of these two sequences identified, we tried to analyse the transition leading from one role to the other, as well as the actions deployed by $R$ and by the other participants during such course of action.

3. Learners had to pass an Internatioanl English Language Test System (IELTS) test before being admitted at University for a degree. According to $R$, this group had a higher level, between 5 and 6 . IELTS level 4 corresponds to Common European Framework (CEFR) level B1 (cf. http://www.ielts.org/teachersandresearchers/ commoneuropeanframework/article236.aspx)

4. Teaching English to Speakers of Other Languages.

5. Certificate in English Language Teaching to Adults ( $c f$. http://www.cambridgeesol.org/exams/teachingawards/celta.html)

6. Didactique des Langues, des Textes et des Cultures, Université Paris 3 Sorbonne Nouvelle: http:// recherche.univ-paris3.fr/2R1-S1-EA2288.php

7. Interactions, Corpus, Apprentissages, Représentations, University Lumière, Lyon 2: http://icar.univlyon2.fr/ 
What we seemed to discover is a rather systematic conversational strategy used by $R$ : shifting from a L2 expert role to a participant role by displaying personal information about likes, phobias, and past experiences. In terms of the conversational tone that $R$ displayed while interacting with learners, we found out quite a recurrent conversational style that had $R$ often making humorous remarks about learners' actions and opinions, but also about $R$ 's own actions and opinions. We would like to illustrate these interpretations with some excerpts.

\subsection{Analysis of excerpts}

Each of the following excerpts is followed by a short analysis; each analysis reproduces, in a slightly simplified manner, remarks and observations similar to the ones found in conversational analysis ${ }^{8}$.

Excerpt 1: "Doing hair" (19 seconds, 13 April, 2007).

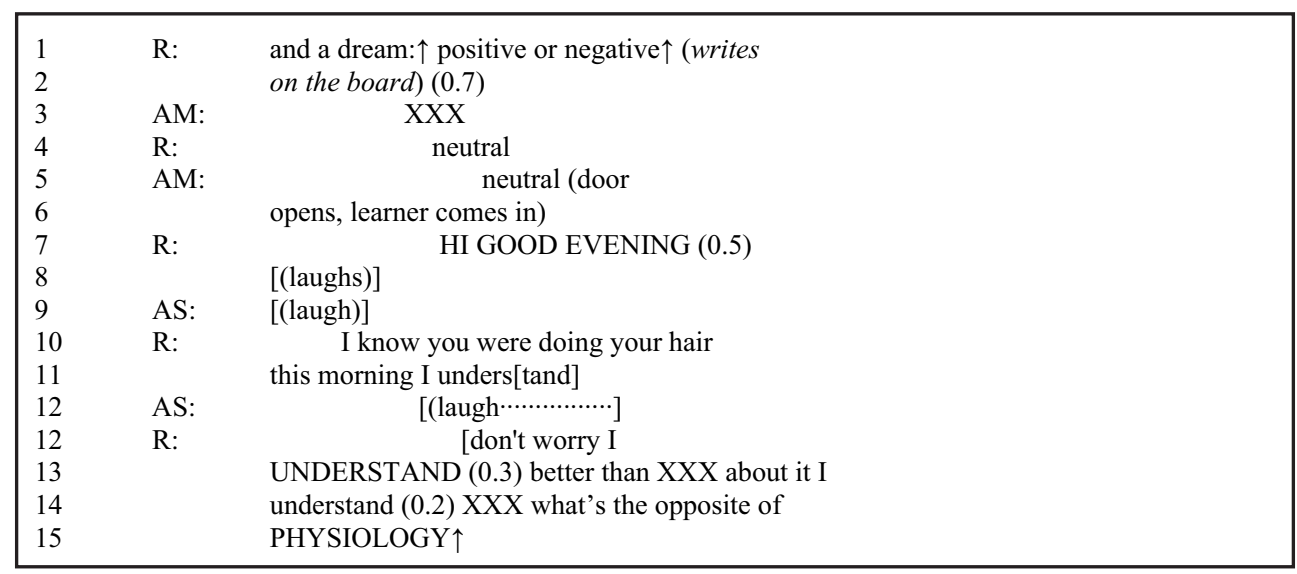

As a pre-reading activity, $R$ asks learners general questions about dreams, the subjectmatter of a text $R$ is about to hand out to learners (lines 1-5). A learner comes in the class (line 5), which triggers a witty remark from $R$ (line 6 ) followed by a commentary about the possible reason for the learner's late arrival (lines 8-12), after what $R$ resumes the discussion of words from the text (line 13).

8. Cf. Bigot, 2005; Markee \& Kasper, 2004; Schegloff et al., 2002; Seedhouse, 2005. 
Excerpt 2: "Philosopher's beard" (27 seconds, 19 April, 2007).

\begin{tabular}{|c|c|c|}
\hline 1 & AF: & {$[\mathrm{XXX}]$} \\
\hline 2 & $\mathrm{R}:$ & [which] countries FLY these FLAGS $\uparrow+\mathrm{A} \uparrow(0.6)$ \\
\hline 4 & AF: & eh: (0.3) India (0.2) \\
\hline 5 & $\mathrm{R}:$ & yeah $($.$) how do you-$ \\
\hline 6 & & WHAT's the thing in the middle $\uparrow(0.4)$ \\
\hline 7 & AM: & $\mathrm{s}:[\mathrm{ymbol}]$ \\
\hline 8 & AM: & {$[\{$ India $\}](0.3)$} \\
\hline 9 & & {$[\{$ India $\}]$} \\
\hline 10 & $\mathrm{R}:$ & [IT'S A SYMBOL] WELL DONE \\
\hline 11 & AF: & yeah [and] \\
\hline 12 & $\mathrm{R}:$ & [of] what $\uparrow$ \\
\hline 13 & AM: & [it's not a sun] \\
\hline 14 & AF: & {$[\mathrm{XXX}]$} \\
\hline 15 & AM: & [the:::] \\
\hline 16 & AF: & {$[\mathrm{XXX}]$} \\
\hline 17 & AF: & \{it's \\
\hline 18 & & XXX's\} SUN (0.3) \\
\hline 19 & AM: & $\mathrm{XXX \uparrow}$ \\
\hline 20 & AF: & $\mathrm{XX}[\mathrm{X}]$ \\
\hline 21 & $\mathrm{R}:$ & [I] th-I think it's a \\
\hline 22 & & symbol of the Hin-HINDI reLIgion + isn't \\
\hline 22 & & {$[\mathrm{it}] \uparrow$} \\
\hline 23 & AM: & {$[\mathrm{XXX}]$} \\
\hline 24 & AM: & eh:: \\
\hline 25 & $\mathrm{R}:$ & [I think] \\
\hline 26 & AF: & {$[\mathrm{XXX}]\{$ Hindu $\mathrm{XXX}\} \uparrow$} \\
\hline 27 & $\mathrm{R}:$ & Hindu religion + yeah + \\
\hline 28 & & Hindi + Hindi's the adjective \\
\hline 29 & AF: & {$[\mathrm{XXX}]$} \\
\hline 32 & $\mathrm{R}:$ & [and Hindu]'s \\
\hline 33 & & the religion $(0.3)$ yeah $\uparrow$ alright $\uparrow(1.2)$ \\
\hline 34 & & (chuckles) \\
\hline 35 & AS: & [(laugh)] \\
\hline 36 & $\mathrm{R}:$ & [you look ve-you look] like you \\
\hline 37 & & [know what you're talking about] \\
\hline 38 & AS: & [(laugh)] \\
\hline 39 & $\mathrm{R}:$ & see if $\{$ you $\}$ could have a BEARD \\
\hline 40 & & you'd look [like a philosopher] \\
\hline 41 & AS: & [(laugh)] \\
\hline 42 & $\mathrm{R}:$ & nah:: T-T's been $(0.4)$ \\
\hline 43 & & dancing \{night out] [\{outside $\}]$ \\
\hline 44 & KE: & [is this]-is this a \\
\hline 45 & & reason to put a: spot-ah: on the:-on the: \\
\hline 46 & & {$[\mathrm{XXX}]$} \\
\hline 47 & $\mathrm{R}:$ & [this is] OUTSIDE of my KNOW[LEDGE] \\
\hline 48 & AS: & {$[($ laugh) $\cdots \cdots \cdot \cdot]$} \\
\hline 49 & $\mathrm{R}:$ & [has \\
\hline 50 & & anyone's been to India $] \uparrow(0.7)$ \\
\hline 51 & AF: & no: \\
\hline 52 & AM: & [no] \\
\hline 53 & $\mathrm{R}:$ & {$[$ no $] \uparrow$} \\
\hline 54 & AM: & [no] \\
\hline
\end{tabular}




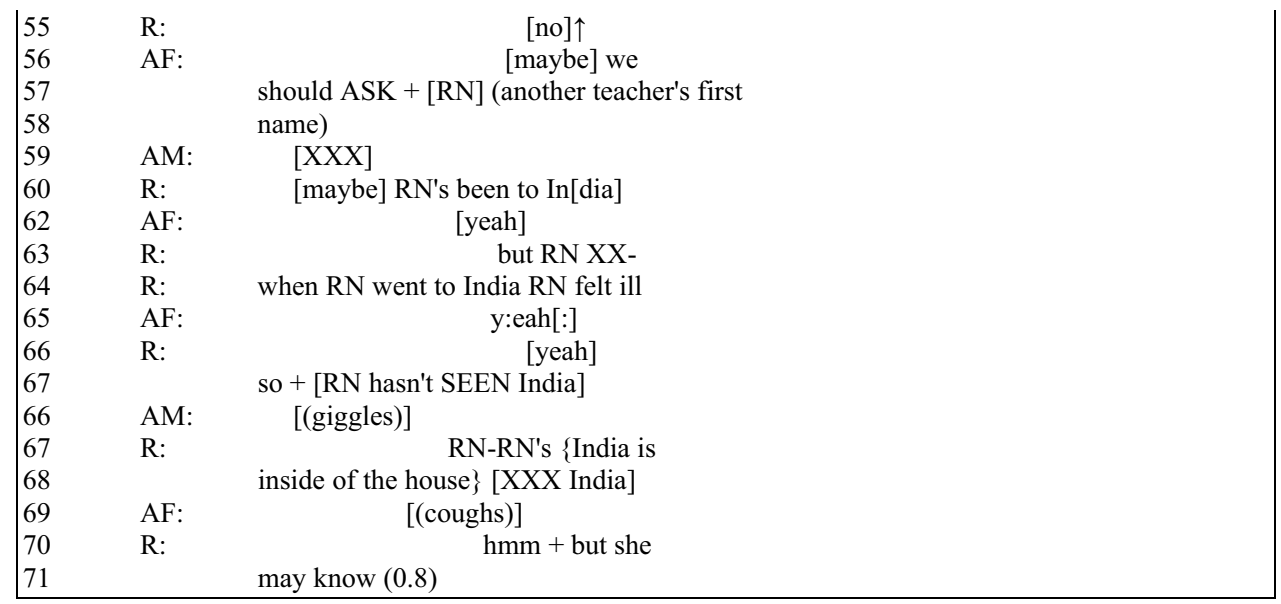

Towards the end of the second lesson we observed, $R$ handed out a document to learners, in which pictures and names of countries had to be matched. Excerpt 2 above comes during the correction of the activity; $R$ starts a part of the activity where countries have to be matched with flags (line 2). Some time is spent trying to figure out what the symbol on the flag represents (lines 5-21), which leads $R$ suggestion that the symbol stands for Hindu religion (lines 22-24). $R$ then addresses one learner, about whom he makes two remarks - one about learner's physical aspect, the other one about what he may have done at night - that make the group laugh (lines 36-44). $K E$ asks $R$ a question $R$ says cannot answer, which makes group laugh (lines 44-48). In lines 56-57 learner $A F$ suggests asking teacher $R N$, so they can have an explanation to what the symbol on the flag represents; an exchange thus starts between $R$ and $A F$, in which $R$ uncovers the implicit idea apparently underlying learner $A F$ 's suggestion (line 60), and then has $R$ question the validity of $A F$ 's suggestion by arguing that teacher $R N$ was ill while being in India, which would invalidate $R N$ 's testimony (lines 6468). The sequence ends with $R$ acknowledging $R N$ may know what the symbol stands for. 
Excerpt 3: "Breakfast and conferences" (1 minute 9 seconds, 19 April 2007).

\begin{tabular}{|c|c|c|}
\hline 1 & $\mathrm{R}:$ & ACTUAL + remember we talked-WE TALKED about \\
\hline 2 & & actual yesterday $\uparrow+$ didn't we $\uparrow$ \\
\hline 3 & AM: & 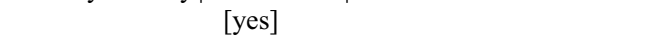 \\
\hline 4 & $\mathrm{R}:$ & [what was] the \\
\hline 5 & & word that we: $\uparrow(0.5)$ we FOUND for: $(0.2)$ \\
\hline 6 & & ACTUAL $\uparrow \mathrm{XXX}$ in fact $\uparrow+$ actually $\uparrow(0.3)$ \\
\hline 7 & AM: & $\{$ essen $\}$ \\
\hline 8 & & $(0.6)$ \\
\hline 9 & AF: & eh:[:] \\
\hline 10 & $\mathrm{R}:$ & [eSSEN]TIALLY $(0.2)$ eSSENtially $(0.3)$ \\
\hline 11 & & remember we used $\uparrow$ (1.1) VERY GOOD \\
\hline 12 & AF: & {$[$ (laughs) $]$} \\
\hline 13 & AM: & [(chuckles)] \\
\hline 14 & $\mathrm{R}:$ & $\mathrm{XXX} \uparrow$ (AM’s first name) I've never seen YOU \\
\hline 15 & & awake beFORE \\
\hline 16 & AM: & (chuckles and [laughs)] \\
\hline 17 & $\mathrm{R}:$ & {$[($ laughs $)]$} \\
\hline 18 & AS: & [(laughs)] \\
\hline 19 & $\mathrm{R}:$ & VERY GOOD \\
\hline 20 & & (0.5) WHAT did you have for BREAKFAST this \\
\hline 21 & & MORNING $\uparrow(0.5)$ \\
\hline 22 & AF: & [(laughs)] \\
\hline 23 & AM: & [dictionary] \\
\hline 24 & $\mathrm{R}:$ & dictionary $\uparrow$ \\
\hline 25 & AF: & [(chuckles)] \\
\hline 26 & $\mathrm{R}:$ & [what did] you have $\uparrow$-what did you have XXX \\
\hline 27 & & $\{$ did you have a $\}$ cup of coffee $\uparrow(0.3)$ \\
\hline 28 & AM: & (.) \\
\hline 29 & & (chuckles) (1.0) \\
\hline 30 & $\mathrm{R}:$ & no $\uparrow(0.4)$ a cigarette $\uparrow$ \\
\hline 31 & AS: & $(\mathrm{lau}[\mathrm{gh})]$ \\
\hline 32 & $\mathrm{R}:$ & [WHATEVER] you HAD: have TWO TOMORROW \\
\hline 33 & AF: & [(laughs)] \\
\hline 34 & $\mathrm{R}:$ & [ok $\uparrow$ (laughs)] \\
\hline 35 & AS: & {$[($ laugh $)](0.2)$} \\
\hline 36 & $\mathrm{R}:$ & (.) (chuckles) (1.2) in the \\
\hline 37 & & FOURTH ONE $\uparrow+$ in th-the case + of a VERY- \\
\hline 38 & & SERIOUS-[COMPLAINT] \\
\hline 39 & AM: & [(clears throat)] \\
\hline 40 & $\mathrm{R}:$ & are we looking for a \\
\hline 41 & & $\mathrm{VERB} \uparrow+$ a no[un $] \uparrow$ \\
\hline 42 & AF: & [a noun] \\
\hline 43 & $\mathrm{R}:$ & an adjective $\uparrow+$ a NOUN $\uparrow$ \\
\hline 44 & AF: & {$[\mathrm{XXX}]$} \\
\hline 45 & AM: & {$[\mathrm{XXX}]$} \\
\hline 46 & AF: & {$[\{$ meeting $\}]$} \\
\hline 47 & AF: & $[$ meeting $\}]$ \\
\hline 48 & $\mathrm{R}:$ & a \{meeting\} $\uparrow$ (board, 4.2) any \\
\hline 49 & & other $\uparrow+$ \\
\hline 50 & AF: & {$[\mathrm{XXX}]$} \\
\hline 51 & $\mathrm{R}:$ & [pos]sible words-a meeting $\uparrow$ \\
\hline 52 & AM: & {$[\mathrm{XXX}]$} \\
\hline 53 & AM: & [contact] \\
\hline
\end{tabular}




\begin{tabular}{|c|c|c|}
\hline 54 & & with customers \\
\hline 55 & $\mathrm{R}:$ & yeah: + contact with customers $\uparrow$ \\
\hline 56 & & + GOOD \\
\hline 57 & AM: & {$[\mathrm{XXX}]$} \\
\hline 58 & AF: & [inter]view $\uparrow$ \\
\hline 59 & $\mathrm{R}:$ & interview $+\mathrm{AN}$ interview + \\
\hline 60 & & yeah + remember XXX three words + interview's \\
\hline 61 & & fine $(0.3) \mathrm{AN}$ interview \\
\hline 62 & AM: & conference $\uparrow(0.5)$ \\
\hline 63 & R: & {$[\mathrm{A}] \uparrow$} \\
\hline 64 & AF: & {$[\mathrm{uh}] \uparrow$} \\
\hline 65 & AM: & [con]ference $(0.5)$ \\
\hline 66 & R: & CONVERSA[TION $] \uparrow$ \\
\hline 67 & AF: & [uh] \\
\hline 68 & AM: & conference \\
\hline 69 & $\mathrm{AF}:$ & $\operatorname{con}[$ ference $]$ \\
\hline 70 & $\mathrm{R}:$ & {$[\mathrm{a}$ CONFE]rence + a CON $[$ ference $] \uparrow$} \\
\hline 71 & AF: & {$[($ chuckles $)]$ where } \\
\hline 72 & & someone sPEAKS and we talk about FLIGHTS $\uparrow$ \\
\hline 73 & AM: & (chuckles and [laughs)] \\
\hline 74 & R: & [COULD BE] $(0.5)$ a CONFERENCE \\
\hline 75 & & $\{$ tends $\}$ + in ACADEMIC world + what's a \\
\hline 76 & & CONFERENCE $\uparrow(0.8)$ \\
\hline 77 & AF: & meetings \\
\hline 78 & AF: & {$[\{$ sciences $\}]$} \\
\hline 79 & AM: & {$[\mathrm{XXX}]$} \\
\hline 80 & AM: & {$[\mathrm{XXX}]$} \\
\hline 81 & R: & {$[$ MEETING] $] \uparrow(0.6)$} \\
\hline 82 & AF: & of science \\
\hline 83 & AM: & lecture \\
\hline 84 & $\mathrm{R}:$ & SCIENTISTS for example + \\
\hline 85 & & academics + and what do they do $\uparrow(0.7)$ \\
\hline 86 & AF: & they \\
\hline 87 & & speak about-eh: specific-[eh]: \\
\hline 88 & $\{\mathrm{AF}\}$ : & {$[\{\mathrm{uh}\}](0.2)$} \\
\hline 89 & AM: & {$[\mathrm{XXX}]$} \\
\hline 90 & $\mathrm{R}:$ & [well \\
\hline 91 & & done] so + for example in my subject we have \\
\hline 92 & & (0.2) CO-eh (0.3) CONferences about lin:- \\
\hline 93 & & GUIStics or SOCIOlinguistics-SOCIOlinguistics \\
\hline 94 & & conferences I go to $($.$) sometimes + when I$ \\
\hline 95 & & need to sleep (chuckles lightly) ok $\uparrow$ \\
\hline 96 & & (chuckles) (.) you'll know what I mean in a \\
\hline 97 & & few years if you continue to study $(0.2) \mathrm{hmm}$ \\
\hline 98 & & + sometimes inTERESting + sometimes not $\uparrow \mathrm{XXX}$ \\
\hline 99 & & (0.5) (.) OK (chuckles) + I shouldn't say \\
\hline 100 & & this you'll be good academics + much more \\
\hline 101 & & motivated than me (chuckles) (.) \\
\hline
\end{tabular}


During the correction of a gap filling activity, $R$ tries to elicit the word "essentially" from learners (lines 1-10); in line 7, learner $A M$ utters the two first syllables of the word $R$ is requesting. $R$ confirms and praises (line 10) and then addresses learner $A M$, making a remark that makes some learners laugh (lines 14-18). $R$ continues addressing learner $A M$, asking for some clarification that may explain the allegedly rare fact $R$ has stated in lines 14-15 about learner $A M$, this also makes one learner laugh (line 21). Learner $A M$ answers (line 23) with a leitmotiv - "dictionary for breakfast" - that $R$ used with learners at least twice during the two lessons we observed; $R$ renews question (lines 26-30) suggesting possible answers. $R$ closes the exchange with learner $A M$ by making a sort of witty remark that makes the group laugh (lines 31-35) and then resumes the correction of the activity (lines 37-47). In lines 48$49 R$ tries to elicit a new word from learners; several answers are suggested in lines 50-61; in line 62, learner $A M$ suggests "conference", a proposal that is discussed and then broken down (lines 63-75). $R$ asks learners to define "conference" (lines 75-76); learners come up with ideas and keywords (lines 77-89), before $R$ regains turn (line 90) to praise and then give a more elaborate definition of "conference" (lines 91-101), including first hand experiences (lines 92-94), tongue-in-cheek remarks (lines 94-95) and allegedly tongue-in-cheek implicit remarks about his own academic practice (line 101).

Excerpt 4: "Sleepwalkers and sleeptalkers" (2 minutes 4 seconds, 13 April 2007).

\begin{tabular}{|c|c|c|}
\hline 1 & KE: & what about walksleep $\uparrow(0.6)$ \\
\hline 2 & R: & a-HA: \\
\hline 3 & KE: & yeah $(0.3)$ \\
\hline 4 & $\mathrm{R}:$ & WALKSLEEPING $\uparrow$ \\
\hline 5 & KE: & sleeping [walk] \\
\hline 6 & $\mathrm{R}:$ & [sleep] $\uparrow$ \\
\hline 7 & AM2: & [sleep walk] \\
\hline 8 & $\mathrm{R}:$ & sleep \\
\hline 9 & & walking \\
\hline 10 & AM2: & sleep waling \\
\hline 11 & AM3: & sleep walking $(0.3)$ \\
\hline 12 & $\{\mathrm{R}\}:$ & (chuckles, 0.4$)($ writes on board, 2.9$)$ \\
\hline 13 & & sleep walking $(0.7)$ can you explain what THAT \\
\hline 14 & & is $\uparrow(0.2)$ you're going to say walk in your sleep \\
\hline 15 & & $\mathrm{XXX}$ \\
\hline 16 & KE: & (chuckles, 0.3) \\
\hline 17 & AS: & (laughs, 0.9) (0.6) \\
\hline 18 & KE: & eh: + \\
\hline 19 & SU: & nobody \{really know ( 0.2$)$ nobody knows + eh: \\
\hline 20 & & (0.2) XXX he is (0.4) sleeping XXX walking \\
\hline 21 & $\mathrm{R}:$ & $\mathrm{hmm}$ \\
\hline 22 & & $(0.7)$ \\
\hline 23 & SU: & so $(0.4)$ \\
\hline 24 & KE: & eh: (0.4) yeah but I just MY \\
\hline 25 & & QUESTION about sleep walking if eh: somebody eh: \\
\hline 26 & & (0.2) walks eh:: + when he sleep and: eh: $(0.4)$ \\
\hline 27 & & does he eh: (0.3) DREAM on this eh: $+[\mathrm{XXX}]$ \\
\hline 28 & $\mathrm{R}:$ & {$[$ YEAH] I } \\
\hline 29 & & think your question is what stage of sleeping is \\
\hline
\end{tabular}




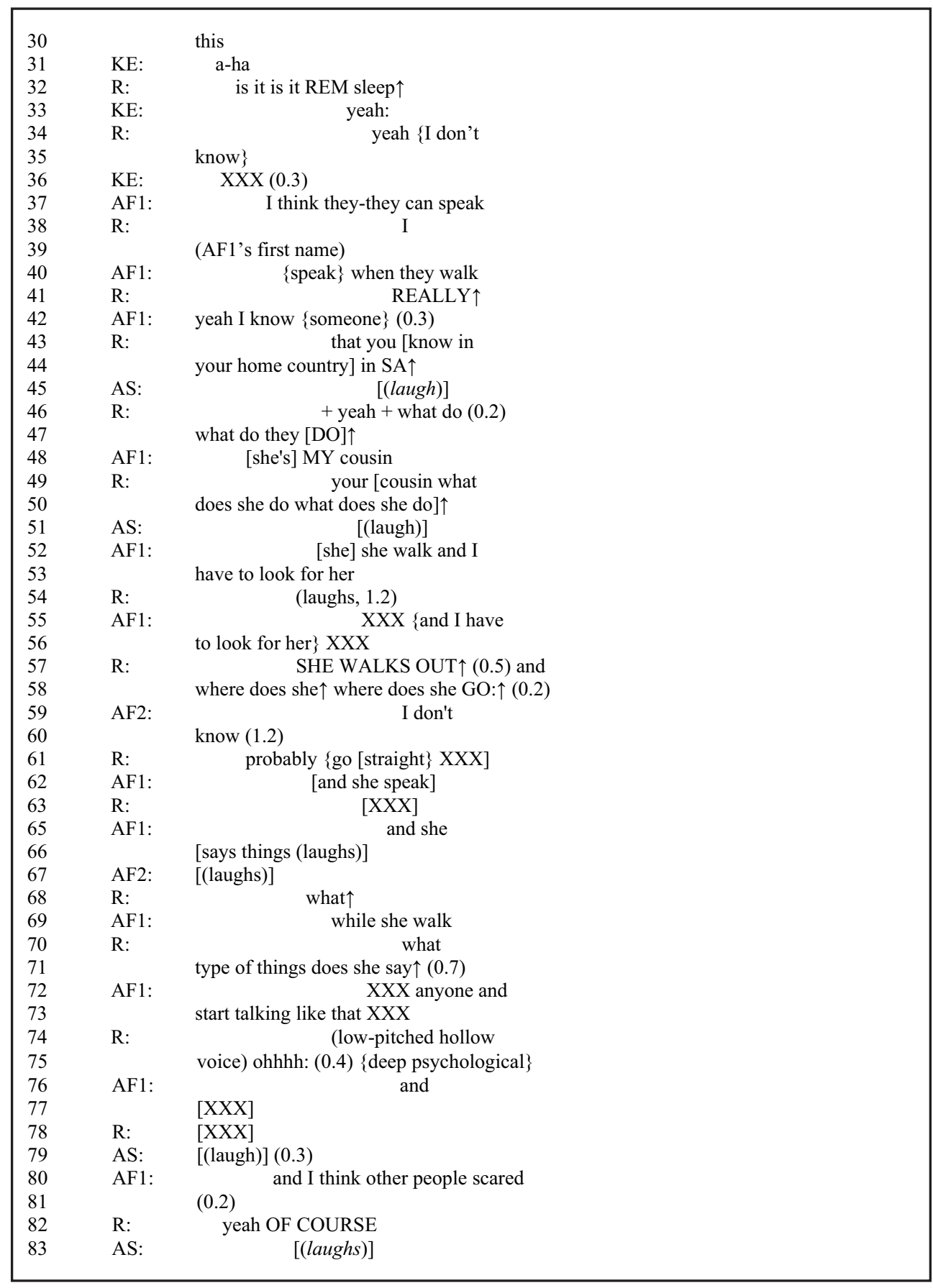




\begin{tabular}{|c|c|c|}
\hline 84 & AF1: & [for me I'm scared] I just \\
\hline 85 & & take her and $(0.2)$ \\
\hline 86 & $\mathrm{R}:$ & $\mathrm{XXX}$ \\
\hline 87 & $\mathrm{AF} 1:$ & (laughing) yeah \\
\hline 88 & R: & $\{\mathrm{I}$ know \\
\hline 89 & & (0.4) XXX \\
\hline 90 & KE: & it's a dangerous situation becau[se:] \\
\hline 91 & R: & [yeah:] \\
\hline 92 & KE: & they:'1l eh: go out and eh for maybe for CARS \\
\hline 93 & & [or streets or] \\
\hline 94 & $\mathrm{R}:$ & [yeah of course] ( 0.8$)$ WHEN I was younger I used \\
\hline 95 & & to SPEAK in my SLEEP $(0.4)$ I used to TALK + in \\
\hline 96 & & my sleep (0.5) it was QUITE eh: (1.6) maybe \\
\hline 97 & & quite dangerous too $(0.5)$ [(burst of laughter) \\
\hline 98 & & $\mathrm{XXX}\{$ it always is $\}]$ \\
\hline 99 & AS: & [(burst of laughter)] \\
\hline 100 & R: & people would ask me questions \\
\hline 101 & & and I would answer (soft laughter, 1.4) \\
\hline 102 & AS: & (burst of \\
\hline 103 & & laughter, 2.1) \\
\hline 104 & $\mathrm{R}:$ & ok \\
\hline
\end{tabular}

As part of a post-activity discussion about dreams, $K E$ brings up the concept of "walksleep" (lines 1-3); this causes $R$ to negotiate with the learners the exact form of the term they want to discuss (lines 4-11). $R$ tries to elicit a more elaborate production from $K E$ (lines 12-13), by virtue of an injunction that $R$ seems to discard immediately (lines 13-14). SU intervenes spontaneously (lines 18-22), before $K E$ attempts to link the concept he has introduced with a question (lines 23-26), which is interpreted by $R$, and put in relation with other concepts that have previously been discussed (lines 27-33). $R$ declares his incapacity to answer $K E$ 's question (line 34), followed by $A F 1$ 's spontaneous intervention (line 36), which seems to appeal to $R$, who repeatedly asks $A F 1$ to elaborate in more detail (lines 39, 41, 44, 46-47, 53 54). $R$ seems to try to regain the turn (line 56), but $A F 1$ does not seem willing to give up hers, which forces $R$ to ask $A F 1$ for repetition (line 61), and hence to resume a position of listener, responsible to encourage $A F 1$ 's narration (lines $63,71,76$ ). $K E$, who has originally introduced the concept of "sleepwalkers", suggests a new sequence by introducing the notion of "danger" as one possible negative consequence for sleepwalkers (lines 77-80); $R$ acknowledges $K E$ 's attempt but does seem to be willing to pursue it (line 81 ). $R$ continues the sequence by telling learners about his own experience as sleepwalker (lines 81-83); $R$ seems to acknowledge $K E$ 's suggested but not pursued new sequence on "danger" (line 84 ), and carries on to explain the scope of danger in his past as sleepwalker (lines 87-88), which causes the group's laughter. 


\section{Discussion}

The previous excerpts illustrate how in relatively short sequences teacher $R$ 's discourse shifted from a function as a L2 expert to another as a participant. As an expert in the L2, $R$ could voluntarily check on learners' understanding, especially in terms of lexicon required for the accomplishment of specific activities (excerpts 1 and 3). Also, R's L2 expertise was required by learners needing explanations for unclear terms; $R$ dealt with these requests (a) giving explanations right away ("conference" in excerpt 3, line 74) or (b) instilling exchanges among learners in order for them to try out their hypotheses ("conference" in excerpt 3 , lines 77-90; "sleepwalker" in excerpt 4, lines 18-20).

Instances where explanations are given right away show that $R$ may choose to exemplify by drawing from personal experiences (excerpt 3, lines 91-101); $R$ may also exemplify by presenting own experiences after a debate has been instilled among learners (excerpt 4 , lines 94-101). In either case, and once $R$ has introduced personal elements in the exchange, the turn seems to be exclusively owned by $R$; it seems to be up to $R$ to dispose for learners to regain turn again. The implication here seems to be that whenever $R$ introduces personal elements in the interaction, a certain monopoly of turn is attained that only $R$ seems allowed to break up. The presentation of these personal elements thus implies taking away time from learners, who cannot try out their productions - provided they had any - for as long as $R$ is delivering personal information. This observed exchange feature would seem contradictory with a pedagogical that $R$ expressed while being interviewed": "if we're trying to be communicative, then [learners] need more chances to speak than I do". During this interview, $R$ also referred to typical interaction with this particular group as "less of a monologue, more of an interaction". We seem to notice a gap between $R$ 's discourse ideals and $R$ 's actual interaction in class with learners.

Other than the suggested pedagogical implications, we may suggest a possible interpretation for $R$ 's introducing personal elements in own discourse: being at the learners' service may prove to be a burden at times ${ }^{10}$; as a L2 teacher, $R$ may hence sometimes stop attending learners' needs momentarily and turn towards a slight reaffirmation of self. During our focus session, $R$ suggested that "when you're teaching you're still a normal person, so your own personality is reflected on that too". According to $R$, and in terms of pedagogical actions, one possible implication of this "personality reflection" may be that "as well as amusing [learners] I'm amusing myself". This would seem consistent with $R$ 's analysis of some particular class exchanges, commented as "constructing a little bit of who I am".

We see frequent moments of laughter in $R$ 's classes: in line 75, excerpt 4, where $R$ utters a sort of phantom-like voice as a reaction to $A F 1$ 's turn in line 74 , one could argue that by

9. This focus session was held in the Language Centre, at Glasgow University, last 5 March 2008. The session, which was tape-recorded, ran for 1 hour 13 minutes; what we did was to show $R$ ten excerpts chosen from the two observed lessons, in order for $R$ to comment the excerpts in terms of what was felt at the time, what was felt while listening to the excerpts one year later, and what the pedagogical rationale behind the actions was.

10. Nonnon (op. cit.: 79-81) warns about the potential cognitive risks of enduring listening positions. 
doing such a voice, $R$ is showing other learners what $A F 1$ means by "talking like that", and thus making sure that all learners follow the narration. However, the fact that $R$ 's low-pitched hollow voice causes learners to laugh may make us wonder if $R$ 's is not attempting to share intimacy with learners precisely by causing them to laugh ${ }^{11}$. Laughter also manifests, recurrently and systematically, whenever $R$ "has a go" at a learner (excerpt 1, lines 10-11; excerpt 2, lines 39-40; excerpt 3, line 32) or even at self (excerpt 3, line 101). This seems to confirm $R$ 's manifested idea ${ }^{12}$ of the atmosphere that should govern the class: an "easier approach", not necessarily a "fun place, but a non threatening" one. This also seems consistent with $R$ 's perception of the learners having chances to express themselves as a particular problem in EAP classes. $R$ suggested that "if [the students] feel that the atmosphere is jovial, or caring, or warm, then they are more likely to express themselves in the class". According to $R$, laughter may be a means to keep learners interested.

\section{Conclusion}

Becoming interested in highly detailed, specific aspects of teachers' discourse may be a valuable tool to have a better understanding of teachers' logics as they are confronted with unexpected situations, which may ask for unforeseen choices. Whereas certain aspects may be programmed in task-based and communicative classes (such as dates, evaluation criteria, number of participants), there is a human dimension that can hardly be predicted. This human component may be of importance in pedagogical contacts where different motivations and different goals live together, and in the same room. Trying to gain a better understanding of specific human aspects of pedagogical relations may prove useful in order to improve learning and teaching processes.

Through $R$ 's own analysis of class interactions, a more or less well formed ideal of what class interaction should be seemed to emerge: a warm atmosphere and frequent laughter seemed to be positively evaluated by $R$, who also seemed to search for opportunities where learners or self could "express themselves", sometimes by the display of personal information, as a means to attain this ideal classroom interaction. The excerpts selected from our classroom observation fieldwork may answer to the question "how is this ideal interaction achieved", by suggesting some features outlining $R$ 's profile as a L2 teacher. Some of these features may include:

- Frequent self-disclosure while interacting with learners.

- Seemingly active search of laughter on self and others while in interaction.

- Use of past personal background as a means to exemplify L2 aspects or contents.

- Use of mocking/tongue in cheek tone with learners and also about self.

11. Cf. Jefferson, Sacks \& Schegloff (1987)

12. Once the two classroom observations were completed, a first interview was conducted with $\mathrm{R}$ in April 2007 at Glasgow University. This interview runs for 1 hour 15 minutes and it was tape-recorded. 


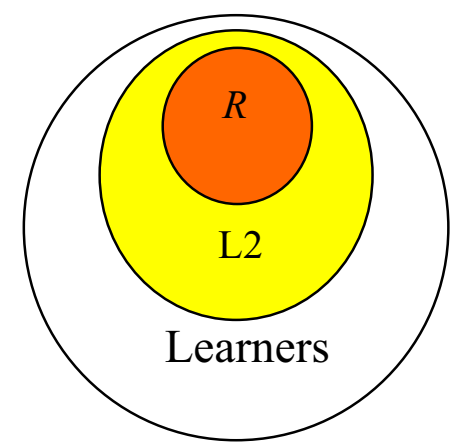

Figure 1: R's interaction with learners schema.

Our research suggests (a) that these features are quite characteristic of $R$ 's teaching; (b) that there are pedagogical principles and principles of a different nature (personal, affective, etc.) underlying specific actions performed by $R$ while interacting with learners ${ }^{13}$. Further research should clarify whether similar teaching features can be found in other teachers.

The limited span of our current classroom interaction research, does not allow us to make any suggestions about the effect that particular teaching styles may have on ongoing language learning and acquisitional processes. A longitudinal comparative study that would analyse interactions between learners and L2 teachers may show the influence specific teaching styles may have learning processes and the suitability of specific teaching styles.

\section{Transcribing COnVention}

(0.2), pause measured in tenths of seconds

+ , pause shorter than 0.2 seconds

$:,:,:::$, syllable progressively lengthened

$\uparrow$, rising intonation

(.), breath intake

$[\cdots \cdots \cdot$, ongoing action

[Fragment]

[Fragment], two speakers speaking simultaneously

* fragment*, language different from L2

/fragment/, phonetic transcription

(fragment), observer's remark/additional information

FRAGMENT, loud utterance

Frag-ment, syllables clearly separated

\{fragment , observer uncertain of transcription

$\mathrm{XXX}$, incomprehensible

13. For an extremely detailed reflection on pedagogical principles and classroom actions, see Breen et al., 2001. 


\section{REFERENCES}

Aguilar Río, J. I. (In press). «Entre feinte et réalité: un équilibre fragile pour l'enseignant de L2", in N. Auger, F. Dervin \& E. Suomela-Salmi (eds.). Pour une didactique des imaginaires dans l'enseignement-apprentissage des langues étrangères. Paris: L'Harmattan.

Berard, E. (1991). L'approche communicative: théorie et pratique. Paris: CLE International.

Bigot, V. (2005). "Quelques questions de méthodes pour une recherche sur la construction de la relation interpersonnelle en classe de langue: primauté des données et construction des savoirs». Le français dans le monde (Les interactions en classe de langue), 42-53.

Bogaards, P. (1988). Aptitude et affectivité dans l'apprentissage des langues étrangères. Paris: Crédif-Didier.

Breen, M. P., Hird, B., Milton, M., Oliver, R., Thwaite, A. (2001). «Making Sense of Language Teaching: Teachers' Principles and Classroom Practices». Applied Linguistics, 22(4), 470501.

Cicurel, F. (1998). Manifestation de l'émotion dans l'interaction didactique. Paper presented at the Colloque sur les émotions, Université de Lyon.

Cicurel, F. (2002). «La classe de langue: un lieu ordinaire, une interaction complexe». AILE, 16, $145-163$.

Cicurel, F. (2005). «La flexibilité communicative: un atout pour la construction de l'agir enseignant». Le français dans le monde: Recherches et applications (Les interactions en classe), 145164.

Dausendshön-Gay, U. \& Krafft, U. (1991). «Rôles et faces conversationnels: à propos de la figuration en situation de contact». Interactions en langue étrangère. Aix-en-Provence: Publications de l'Université de Provence, 37-48

Markee, N. Kasper, G. (2004). «Classroom Talks: An Introduction». The Modern Language Journal, 88(4), 491-500.

Mondada, L., \& Pekarek Doehler, S. (2004). «Second Language Acquisition as Situated Practice: Task Accomplishment in the French Second Language Classroom». The Modern Language Journal, 88(4), 501-518.

Narcy-Combes, J. P. (2005). Didactique des langues et TIC: vers une recherche-action responsable. Paris: Ophrys.

Noels, K. (2001). «Learning Spanish as a Second Language: Learner's Orientations and Perceptions of Their Teachers' Communication Style». Language Learning, 51(1), 107-144.

Nonnon, E. (2004). «Écouter peut-il être un objectif d'apprentissage ?». Le français aujourd'hui, $146,75-84$.

Nunan, D. (1989). Designing Tasks for the Communicative Classroom. Cambridge: CUP.

Schegloff, E., Koshik, I., Jacoby, S., Olsher, D. (2002). «Conversation analysis and applied linguistics». Annual Review of Applied Linguistics, 22, 3-31.

Seedhouse, P. (2005). «Conversation Analysis and language learning». Language Teaching, 38, $165-187$. 